\title{
Effects of Glosses and Reviewing of Glossed Words on L2 Vocabulary Learning through Reading
}

\author{
Makoto Yoshii \\ Prefectural University of Kumamoto \\ doi: http://dx.doi.org/10.7820/vli.v03.2.yoshii
}

\begin{abstract}
This study is an attempt to integrate incidental and intentional vocabulary learning in a reading activity without sacrificing the enjoyment of reading. The paper reports on a study which examined the effectiveness of a reading program on the web. The program contained glosses in a text and a reviewing component at the end of reading. The learners read the text for comprehension purposes on computers and were able to look up certain words by clicking on them. At the end of the reading the learners were also able to review the words they had looked up during the reading. This study examines how well learners can pick up words through this reading program. This study also examines the effectiveness of a reviewing activity by comparing the words reviewed and the words not reviewed. The study investigates if there are any differences in immediate and medium-term effects for vocabulary learning. Data from a pretest one week prior to the experiment, an immediate test right after the reading, and a delayed test were used for the analysis. Lookup behaviors of glosses and reviewing behaviors were also taken into account for analyzing the data.
\end{abstract}

\section{Introduction}

Integration of incidental and intentional learning has been one of the key issues in second language learning (Ellis et al., 2009; Hulstijn, 2005). It is of particular interest to second language vocabulary researchers (File \& Adams, 2010; Hulstijn, 2001; Schmitt, 2008). Research indicates that L1 speakers incidentally acquire around $15 \%$ of the unknown words they encounter while reading (Swanborn \& De Glopper, 1999). L2 learners can also learn vocabulary as they read for comprehension (Horst, Cobb, \& Meara, 1998). L2 word learning through reading, however, often suffers from small gains, slow process, and requires repeated encounters with words (Waring \& Takaki, 2003). Studies have examined ways to promote better efficiency to L2 incidental vocabulary learning. One of the prominent techniques is glossing and studies have shown its effectiveness, especially in the CALL environment (Yun, 2011). Studies have also pointed out that an intentional component is necessary in order to promote greater efficiency to incidental vocabulary learning (Laufer, 2005; Pellicer-Sanchez \& Schmitt, 2010; Schmitt, 2008; Wesche \& Paribakht, 2000). This study is an attempt to add an intentional component to incidental vocabulary learning in a reading activity. The intentional component was added with care so that it will not interfere with the 
reading activity itself or reducing the pleasure of reading. The learners were foretold about the reading comprehension test but not about vocabulary test. In this sense, the notion of intentional learning in this study differs from that of other studies which regard intentional learning as learning with anticipation of some sort of test after an activity (Hulstijn, 2001). Intentional learning in this study means an additional exposure to words they encounter in the reading. The study also incorporated individualized learning by providing an opportunity to review, but not all the words in the text, but only those learners actually looked up during reading. Technology was utilized to conduct this study and the whole reading and testing procedures were implemented with an online reading program.

\section{Theoretical Underpinnings of the Study}

Glosses are definitions or explanations of difficult words provided in the margins of a text. Studies have reported the effectiveness of glosses for enhancing incidental L2 vocabulary learning using printed materials (Hulstijn, 1992; Hulstijn, Hollander, \& Greidanus, 1996; Jacobs, Dufon, \& Hong, 1994; Knight, 1994; Paribakht \& Wesche, 1996; Watanabe, 1997). As technology advanced and became ubiquitous, glosses expanded gloss types to include multimedia elements such as graphics, videos, and audios. Studies have shown the effectiveness of multimedia glosses for L2 vocabulary learning (Abraham, 2007; Chun \& Plass, 1996; Plass, Chun, Mayer, \& Leutner, 1998; Yeh \& Wang, 2003; Yoshii, 2006; Yoshii \& Flaitz, 2002). In spite of a plethora of types of glosses available today, L2 learners often prefer simple textual information (Davis \& Lyman-Hager, 1997; Erçetin, 2003; Laufer \& Hill, 2000; Laufer \& Kimmel, 1997; Lomicka, 1998; Pardo-Ballester \& Rodríguez, 2010).

Are there any other ways to further enhance incidental L2 vocabulary learning besides glossing? Studies have clearly demonstrated that word-focused activities after reading promote more vocabulary gains than reading-only conditions do (Hill \& Laufer, 2003; Sonbul \& Schmitt, 2010; Paribakht \& Wesche, 1996). According to noticing theory (Schmidt, 1990, 1992), attention is a prerequisite for learning. In order to promote the initial stage of form-meaning mapping, increased attention to words is crucial (Godfroid, Boers, \& Housen, 2013; Laufer, 2005). Even though glosses could direct readers' attention to words and encourage the processing of word meanings during reading, word-focused tasks after reading are needed to bring better retention of words. Schmitt (2008) overviewed current L2 vocabulary learning research and acknowledged the importance of including both incidental learning and explicit, intentional learning. He also pointed out the importance of learners' engagement with word learning. This concurs with the Involvement Load Hypothesis (Laufer \& Hulstijn, 2001) and reminds us of the importance of creating tasks which would promote more involvement of learners motivationally and cognitively.

Based on these theories, the researcher added both glossing and reviewing components to the reading program. The review part was unique in that it was an individually customized review of the words learners had looked up during reading. Each learner has a different list of the reviewed words based on his or her lookup behavior. It is hypothesized that this individualization would lead to more learner engagement and encourage more reviewing. As a result, this additional exposure and attention to words would promote better learning. 


\section{The Study}

\subsection{Purpose of the Study}

The purpose of the study is to investigate the effectiveness of a reading program on the web which contains glossing and reviewing components. It is also to examine the effectiveness of customized vocabulary review in the reading program. The study examines the effectiveness of this additional review exercise for vocabulary learning by comparing the learning rates of the words reviewed and those not reviewed.

\subsection{Research Questions}

This study asks the following four research questions:

When learners read a text for comprehension,

(1) does the combination of glossing and reviewing promote vocabulary learning on the immediate test?

(2) does the combination of glossing and reviewing promote vocabulary retention on the delayed test?

(3) does reviewing of words they looked up during reading make a difference on the immediate test?

(4) does reviewing of words they looked up during reading make a difference on the delayed test?

\subsection{Participants}

The participants were 39 university students in Japan. They were freshmen majoring in English. Their average age was 19 years old and they had at least 6 years of English learning experience at junior and senior high schools.

\section{Materials}

A 300-word text was provided using the Moodle learning management system. This system had been used from the beginning of the term as a class management system. Therefore, the learners were familiar with the system. The text dealt with Jacques Rousseau, "One Gentle Writer Who Changed the World" as the title described. The readability of the text was 12 th grade level with 41 points for the reading ease score measured by Flesch-Kincaid test. The text contained mostly words from the most frequent 1,000 word families $(84 \%)$ and the second most frequent 1,000 word families (3\%). This amounted to $87 \%$ of the words in the text. A small portion (5\%) were from the Academic Word list (Coxhead, 2000) and the remaining words were not on the lists $(8 \%)$. The text included 20 target words that were highlighted and clickable. The target words consisted of two from the first 1,000, two from the second 1,000, three from the Academic Word list, and 13 words from outside the lists. L1 glosses appeared as learners clicked on the words. Figure 1 shows the actual screenshot of the text and one word being looked up. 
文中でオレンジ色ななっている単語は、クリックするとその意味が表示されます。碓詔をしたら○Кをクリックしてくたさい。

One Gentle Writer Who Changed the World

\begin{abstract}
Many of us who despair about the world's problems of overpopulation, pollution, global warming and starvation feel helpless to change things. While we care about these problems, and may even feel despondent by them, there seems to be nothing we can do about them. But for inspiration we should study the lesson of one gentle soul who lived more than 200 years ago. The lesson of this man is not how to surmount such specific global problems, but rather that one person-even alone-can make a difference.

This man, who was born in Switzerland and spoke French, wrote books about human rights and social equality. He believed that the greatest problems in the world were ingrained in the erroneous belief that money and political power made one person more worthy than another. He observed that 'civilization' destroyed the inherent value of the individual.

In his day, a small perce sage
peasantry. The nobility
and an apathetic queen. violence. The later constitutions of these nations were also based on his beliefs.

In setting forth his views that all people are created equal and that everyone should be given the opportunity to develop themselves to their fullest potential, this placid, gentle man altered the foundation of the western social and political system. He introduced the concept of human rights, which we now take for granted.

This man will go down in history as one of the world's greatest sages. His name is Jean-Jacques Rousseau.
\end{abstract}

Figure 1. Actual Screenshot of the Text and a Word Being Looked Up.

The reading program stored learners' lookup behaviors and, at the end of the reading activity, provided a list of the words the learners looked up. The learners were able to review the meanings by clicking on the words as seen in Figure 2.

\title{
4.1 Procedures
}

All the activities were part of regular classes. They were language skill classes and particularly focused on reading and listening. A pretest was administered to the participants one week prior to the study. It was a multiple-choice test conducted on Moodle. The learners had to choose the best meaning out of four L1 meanings. The reading activity was provided at the next class a week later. The participants read the text on Moodle at the individual computers. Learners had a chance to review the words they clicked on at the end of the reading as in Figure 2. After the reading, a comprehension test was given as it had been told beforehand. Following the comprehension test, a vocabulary test (the immediate test) was unexpectedly administered. It was the same as the pretest except that the order of the questions and the choices in each question were randomly re-arranged. A delayed test was given two weeks after the immediate test. The test format was the same as the pretest and the immediate test. The order of the test items and choices were randomly re-arranged.

\subsection{Data Analysis}

Data from the pretest, the immediate test, and the delayed test were used for the analysis. For analyzing the data for the research questions 1 and 2, an ANOVA 


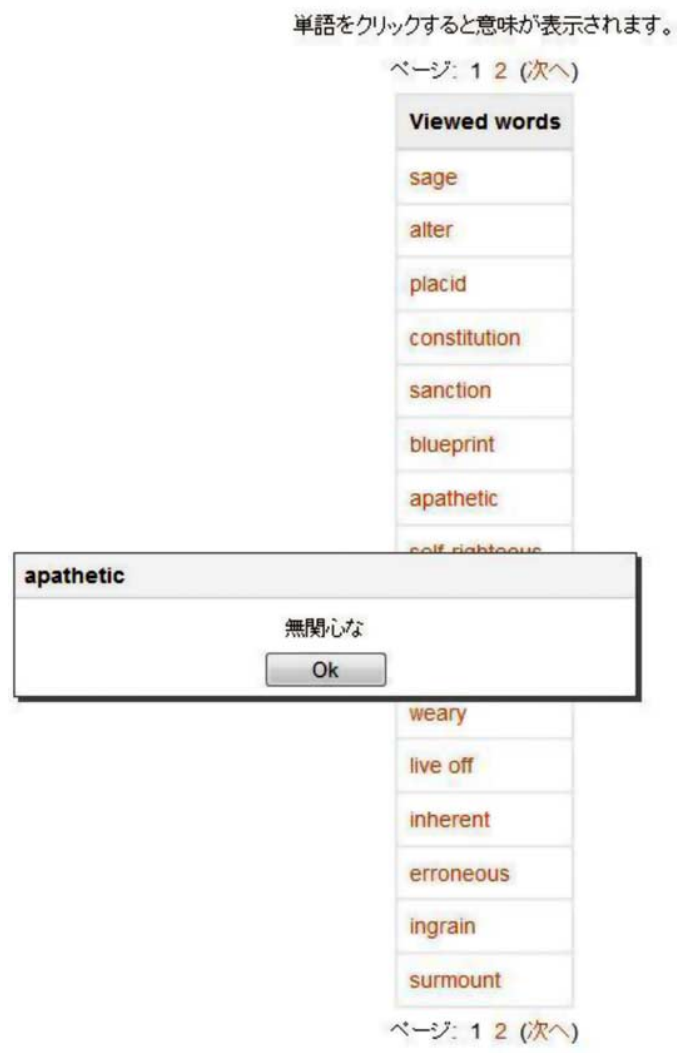

Figure 2. Actual Screenshot of the Review Section.

was used to examine the differences among the tests. When the differences were significant, post hoc analysis was conducted. The unit of analysis for research questions 3 and 4 was each individual target word. For the analyses, first, the words the learners already knew prior to this study shown at the pretest were excluded. From the remaining unknown words, only those the participants actually looked up during reading were selected. In order to compare the reviewed and non-reviewed words, a chi-square test was run on these words. The test examined whether two groups of words, reviewed and non-reviewed, would differ in terms of numbers of correct and incorrect words on the immediate and the delayed tests.

\section{Results}

\subsection{Research Questions 1 and 2: Short-term and Long-term Effects of the Reading Program}

Figure 3 displays the results of the three vocabulary tests: the pretest, the immediate, and the delayed tests. The participants were able to identify almost half 


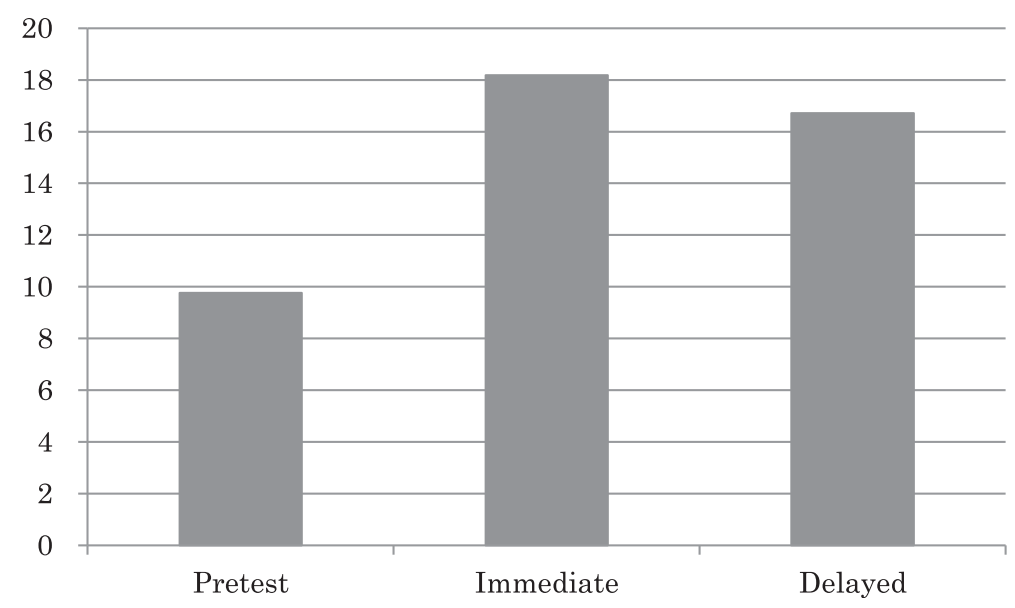

Figure 3. Scores of Three Vocabulary Tests.

of the 20 target words at the pretest $(M=9.8, \mathrm{SD}=2.2)$. The immediate score nearly doubled the score in the pretest $(M=18.2, \mathrm{SD}=2.1)$. The participants sustained the score on the delayed test with a small loss $(M=16.7, \mathrm{SD}=2.5)$. An ANOVA showed statistical significances among the tests $(F(2,76)=230.48$, $p<.01)$. Post hoc analysis using a Bonferroni adjustment $(\alpha=.0167)$ revealed that the scores of both immediate and delayed tests were significantly higher than those of the pretest $(p<.001)$. The combination of glossing and reviewing promoted vocabulary learning through reading as seen on the immediate test and helped the learners retain words as seen on the delayed test.

\subsection{Research Questions 3 and 4: Short-term and Long-term Effects of Reviewing}

The unit of analysis for research questions 3 and 4 was each individual target word. Since the study had 20 target words for each of 39 participants, this amounts to 780 words. Figure 4 recaptures the results of the pretest. The participants already knew 381 words out of 780 words $(49 \%)$ in the study, and these were excluded from the analysis.

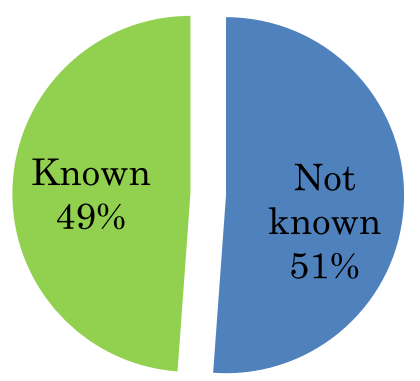

Figure 4. Overview of Pretest Results. 


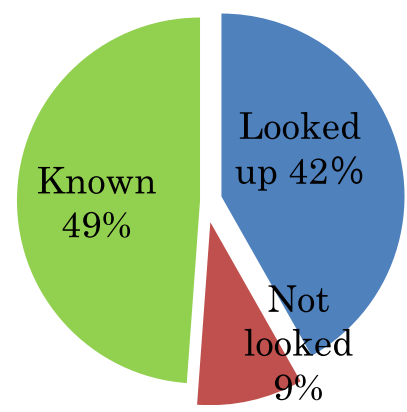

Figure 5. Overall View of Lookup Behavior during Reading.

From the remaining 399 words (51\%), the words the participants actually clicked were selected. Figure 5 shows the overall results of the participants' lookup behaviors of the glossed words. Among all the 780 words in the study, 542 words were looked up $(70 \%)$. This rate of lookup exceeds the rate of unknown words at the pretest $(51 \%)$ and indicates that the students tried to look up even those words they got correct at the pretest. It seems that the students were trying to confirm or verify the meanings of those words. For the analysis of this study, we will use only the looked-up words among unknown words, which amounted to 326 words (42\%).

Then, this group of words, which were unknown at the pretest and looked up during the reading, were further divided between those which were reviewed and those which were not. As Figure 6 indicates, 231 words (30\%) were reviewed and 95 words $(12 \%)$ were not reviewed.

In order to compare the reviewed $(n=231)$ and non-reviewed $(n=95)$ words, a chi-square test was run in relation with the results of the immediate and the delayed tests. The test examined whether two groups of words, reviewed and non-reviewed, would differ in terms of numbers of correct and incorrect words on the immediate and the delayed tests.

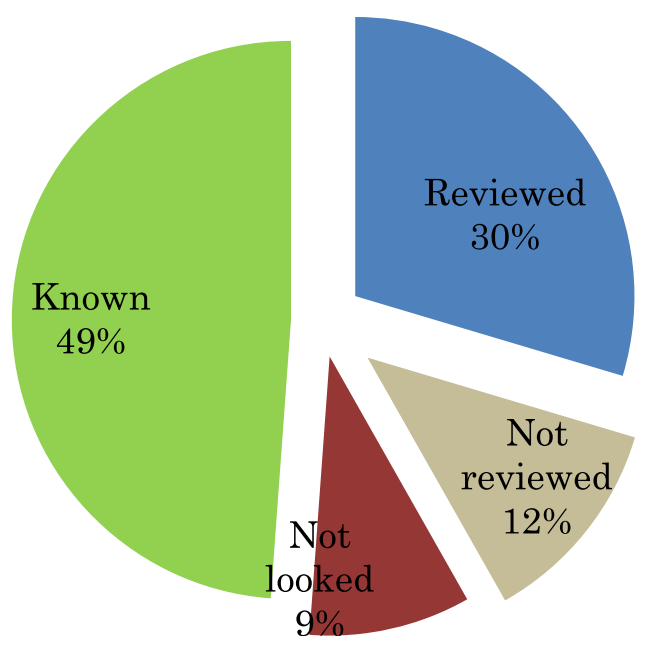

Figure 6. Overall View of the Lookup Behavior during Reviewing. 
Table 1. Cross-tabulation of Group (Reviewed and Not Reviewed) and Results of Immediate Test (Correct and Incorrect)

\begin{tabular}{lrcccc}
\hline Group & \multicolumn{1}{c}{$n$} & Correct & $\%$ & Incorrect & $\%$ \\
\hline Reviewed & 231 & 218 & 94.4 & 13 & 5.6 \\
Not reviewed & 95 & 89 & 93.7 & 6 & 6.3 \\
\hline
\end{tabular}

Table 2. Cross-tabulation of Group (Reviewed and Not Reviewed) and Results of Delayed Test (Correct and Incorrect)

\begin{tabular}{lrcccc}
\hline Group & \multicolumn{1}{c}{$n$} & Correct & $\%$ & Incorrect & $\%$ \\
\hline Reviewed & 231 & 181 & 78.4 & 50 & 21.6 \\
Not reviewed & 95 & 77 & 81.1 & 18 & 18.9 \\
\hline
\end{tabular}

As in Table 1, the results of the immediate test showed that 218 reviewed words turned out to be correct answers; while 13 reviewed words were incorrect. On the other hand, among 95 words not reviewed, 89 words lead to correct answers while six words to incorrect. The ratio of the correct and incorrect answers for both reviewed and non-reviewed words were almost identical. The chi-square test did not show any significant differences between the two groups: $\chi^{2}(1)=.06$, $p=.81$. This indicated the high pick-up rate (94\%) of word learning occurred on the immediate test regardless of reviewing.

As in Table 2, the results of the delayed test showed that 181 reviewed words $(78.4 \%)$ remained as correct answers while 50 reviewed words $(21.6 \%)$ became incorrect. This number of incorrect answers was a big increase from 13 words $(5.6 \%)$ on the immediate test. Among the words not reviewed $(n=95)$, 77 words $(81.1 \%)$ stayed as correct while 18 words $(18.9 \%)$ turned out to be incorrect. The rapid increase of incorrect answers in both groups (around 20\%) indicated the memory loss over two weeks between the immediate and delayed tests.

In order to compare the reviewed and non-reviewed in terms of numbers of correct and incorrect words on the delayed test, a chi-square test was run. The ratio of the correct and incorrect answers on the delayed test was also very similar between reviewed and non-reviewed words. The result did not show any significant differences between the two groups: $\chi^{2}(1)=.30, p=.59$. This indicated that, although word knowledge had already started to decline (the incorrect answers increase from around $5 \%$ on the immediate test to $20 \%$ on the delayed test), the retention rate of the words learned was still high (around $80 \%$ ), regardless of reviewing.

\section{Findings and Conclusions}

The results of the immediate test showed significant gains from the pretest and the learners were able to sustain most of the gains on the delayed test. This was another confirmation of the effect of glossing in reading activity and an indication of the effect of the additional reviewing activity. However, the results of both the 
immediate and the delayed tests did not show any significant differences between the two groups of words: reviewed words and non-reviewed words.

One reason for these results may have to do with a ceiling effect. The immediate result showed a very high learning rate $(94 \%)$ and there was not much room to show any differences between reviewed and non-reviewed words.

A second reason is related to the sensitivity of the instrument. This study used the multiple choice of meaning as the instrument, and it was most likely not enough to detect the change in word knowledge. Laufer, Elder, Hill, and Congdon (2004) proposed the various levels of word knowledge in the form-meaning link and Schmitt (2010) relabeled the description as following four elements: form recall, meaning recall, form recognition, and meaning recognition. If other types or levels of word knowledge in the form-meaning linking stage were tested besides meaning recognition, the differences might have emerged.

A third reason is related to the nature of the reviewing task. The reviewing activity in this study was a simple check on a meaning of each word by clicking. This was purposely designed so that the activity would not impose on the learners a rigorous exercise after the reading activity. The log file of the participants indicated that it was just a matter of a couple of minutes to go through the reviewing. Even if they were exposed to the words again, it might not have been enough to help the participants strengthen their word learning. The reviewing might have not had enough quality to promote the depth of processing necessary for effective learning.

The reason may also be related to the fact that there may not have been a need for reinforcement. The participants had already gained enough during reading with glossing. Glossing might have had a greater impact on word learning in both tests than expected. Regardless of words reviewed or not reviewed, the correct answer rates were extremely high in both tests: $94 \%$ for the immediate and $80 \%$ for the delayed as seen in Tables 1 and 2. It could be that the glossing had already helped the learners make an initial connection between form and meaning, which is a necessary part of word learning (Laufer, 2005).

The effectiveness of reviewing needs to continue to be investigated. Many questions still remain unanswered. How can we effectively integrate incidental and intentional parts into vocabulary acquisition? What are the ways to strengthen word knowledge learners gain while reading without reducing enjoyment in reading? How can we add a reviewing part to incidental vocabulary learning effectively but not intrusively? Further studies are needed to find answers to these questions. Future research could also look at how the participants look up glossing and how they review words. Are there any strategies used by learners? If so, what are they? Qualitative study such as a think-aloud protocol may shed some light on these. Future research could also look at the effectiveness of reviewing, adapting the strict sense of intentional learning. A study could be devised which compared two groups: one group with the announcement of a vocabulary test after the reading activity and the other group without such an announcement. The announcement of the test could be delivered after the incidental stage of reading to determine the effectiveness of reviewing as an intentional component in its full sense. 


\section{Acknowledgments}

This study was partially supported by Grant-in-Aid for Scientific Research (C) [grant number 23520691]. I would like to express my sincere gratitude to Professor Kita at Kumamoto University for creating this reading program, especially the individualized reviewing component. I would also like to express my appreciation to Dr. Laufer for her valuable comments on this study.

\section{References}

Abraham, L. B. (2007). Second-language reading comprehension and vocabulary learning with multimedia. Hispania, 90, 98-108.

Coxhead, A. (2000). A new academic word list. TESOL Quarterly, 34, 213-238. doi: $10.2307 / 3587951$

Chun, D. M., \& Plass, J. L. (1996). Effects of multimedia annotations on vocabulary acquisition. The Modern Language Journal, 80, 183-198. doi:10.1111/j.1540-4781.1996.tb01159.x

Davis, J. N., \& Lyman-Hager, M. A. (1997). Computers and L2 reading: Student performance, student attitudes. Foreign Language Annals, 30(1), 58-72. doi:10.1111/j.1944-9720.1997.tb01317.x

Ellis, R., Loewen, S., Elder, C., Erlam, R., Philp, J., \& Reinders, H. (2009). Implicit and explicit knowledge in second language learning, testing and teaching. Bristol, UK: Multilingual Matters.

Erçetin, G. (2003). Exploring ESL learners' use of hypermedia reading glosses. CALICO Journal, 20, 261-283.

File, K. A., \& Adams, R. (2010). Should vocabulary instruction be integrated or isolated? TESOL Quarterly, 44, 222-249.

Godfroid, A., Boers, F., \& Housen, A. (2013). An eye for words: Gauging the role of attention in incidental L2 vocabulary acquisition by means of eye-tracking. Studies in Second Language Acquisition, 35, 483-517. doi:10.1017/S02722 63113000119

Hill, M., \& Laufer, B. (2003). Type of task, time-on-task and electronic dictionaries in incidental vocabulary acquisition. IRAL - International Review of Applied Linguistics in Language Teaching, 41(2), 87-106. doi:10.1515/iral.2003.007

Horst, M., Cobb, T., \& Meara, P. (1998). Beyond a clockwork orange: Acquiring second language vocabulary through reading. Reading in a Foreign Language, 11, 207-223. Retrieved from http://nflrc.hawaii.edu/rfl/PastIssues/rfl112horst. pdf

Hulstijn, J. H. (1992). Retention of inferred and given word meanings: Experiments in incidental vocabulary learning. In P. Arnaud \& H. Bejoint (Eds.), Vocabulary and applied linguistics (pp. 113-125). London, UK: Macmillan.

Hulstijn, J. H. (2001). Intentional and incidental second language vocabulary learning: A reappraisal of elaboration, rehearsal and automaticity. In P. Robinson (Ed.), Cognition and second language instruction (pp. 258-287). Cambridge, UK: Cambridge University Press. 
Hulstijn, J. H. (2005). Theoretical and empirical issues in the study of implicit and explicit second-language learning. Studies in Second Language Acquisition, 27(2), 129-140. doi:10.1017/S0272263105050084

Hulstijn, J. H., Hollander, M., \& Greidanus, T. (1996). Incidental vocabulary learning by advanced foreign language students: The influence of marginal glosses, dictionary use, and reoccurrence of unknown words. The Modern Language Journal, 80, 327-339. doi:10.1111/j.1540-4781.1996.tb01614.x

Jacobs, G. M., Dufon, P., \& Hong, F. C. (1994). L1 and L2 vocabulary glosses in L2 reading passages: Their effectiveness for increasing comprehension and vocabulary knowledge. Journal of Research in Reading, 17(1), 19-28. doi:10.1111/j.1467-9817.1994.tb00049.x

Knight, S. (1994). Dictionary use while reading: The effects on comprehension and vocabulary acquisition for students of different verbal abilities. The Modern Language Journal, 78, 285-299. doi:10.1111/j.1540-4781. 1994.tb02043.x

Laufer, B. (2005). Focus on form in second language vocabulary learning. EUROSLA Yearbook, 5, 223-250. doi:10.1075/eurosla.5.11lau

Laufer, B., Elder, C., Hill, K., \& Congdon, P. (2004). Size and strength: Do we need both to measure vocabulary knowledge? Language Testing, 21, 202-226. doi:10.1191/02655322041t277oa

Laufer, B., \& Hill, M. (2000). What lexical information do L2 learners select in a CALL dictionary and how does it affect word retention? Language Learning \& Technology, 3, 58-76. Retrieved from http://1lt.msu.edu/vol3num2/ laufer-hill/index.html

Laufer, B., \& Hulstijn, J. (2001). Incidental vocabulary acquisition in a second language: The construct of task-induced involvement. Applied Linguistics, 22(1), 1-26. doi:10.1093/applin/22.1.1

Laufer, B., \& Kimmel, M. (1997). Bilingualised dictionaries: How learners really use them. System, 25, 361-369. doi:10.1016/S0346-251X(97)00028-6

Lomicka, L. L. (1998). To gloss or not to gloss: An investigation of reading comprehension online. Language Learning \& Technology, 1, 41-50. Retrieved from http://1lt.msu.edu/vollnum2/article2/default.html

Pardo-Ballester, C., \& Rodríguez, J. C. (2010). Developing Spanish online readings using design-based research. CALICO Journal, 27, 540-553. doi:10.11139/cj. 27.3.540-553

Paribakht, T., \& Wesche, M. (1996). Enhancing vocabulary acquisition through reading: A hierarchy of text-related exercise types. The Canadian Modern Language Review, 52, 155-178.

Pellicer-Sanchez, A., \& Schmitt, N. (2010). Incidental vocabulary acquisition from an authentic novel: Do things fall apart? Reading in a Foreign Language, 22, 31-55. Retrieved from http://nflrc.hawaii.edu/rfl/April2010/articles/ pellicersanchez.pdf 
Plass, J. L., Chun, D. M., Mayer, R. E., \& Leutner, D. (1998). Supporting visual and verbal learning preferences in a second language multimedia learning environment. Journal of Educational Psychology, 90(1), 25-36. doi:10.1037/ 0022-0663.90.1.25

Schmidt, R. W. (1990). The role of consciousness in second language learning. Applied Linguistics, 11, 129-158. doi:10.1093/applin/11.2.129

Schmidt, R. (1992). Awareness and second language acquisition. Annual Review of Applied Linguistics, 13, 206-226. doi:10.1017/S0267190500002476

Schmitt, N. (2008). Review article: Instructed second language vocabulary learning. Language Teaching Research, 12, 329-363. doi:10.1177/1362168808089921

Schmitt, N. (2010). Researching vocabulary: A vocabulary research manual. Basingstoke, UK: Palgrave Macmillan.

Sonbul, S., \& Schmitt, N. (2010). Direct teaching of vocabulary after reading: Is it worth the effort? ELT Journal, 64, 253-260. doi:10.1093/elt/ccp059

Swanborn, M. S. L., \& De Glopper, K. (1999). Incidental word learning while reading: A meta-analysis. Review of Educational Research, 69, 261-285. doi:10.3102/00346543069003261

Waring, R., \& Takaki, M. (2003). At what rate do learners learn and retain new vocabulary from reading a graded reader? Reading in a Foreign Language, 15, 130-163. Retrieved from http://nflrc.hawaii.edu/rfl/October2003/waring/ waring.html

Watanabe, Y. (1997). Effects of increased processing on incidental learning of foreign language vocabulary. Studies in Second Language Acquisition, 19, 287-307. doi:10.1017/S027226319700301X

Wesche, M. B., \& Paribakht, T. S. (2000). Reading-based exercises in second language vocabulary learning: An introspective study. The Modern Language Journal, 84, 196-213. doi:10.1111/0026-7902.00062

Yeh, Y., \& Wang, C. W. (2003). Effects of multimedia vocabulary annotations and learning styles on vocabulary learning. CALICO Journal, 21, 131-144.

Retrieved from http://journals.sfu.ca/CALICO/index.php/calico/article/view/ 669

Yoshii, M. (2006). L1 and L2 glosses: Their effects on incidental vocabulary learning. Language Learning \& Technology, 10, 85-101. Retrieved from http://lit.msu.edu/vol10num3/yoshii/default.html

Yoshii, M., \& Flaitz, J. (2002). Second language incidental vocabulary retention: The effect of text and picture annotation types. CALICO Journal, 20, 33-58. Retrieved from http://journals.sfu.ca/CALICO/index.php/calico/article/view/ 626

Yun, J. (2011). The effects of hypertext glosses on L2 vocabulary acquisition: A meta-analysis. Computer Assisted Language Learning, 24(1), 39-58. doi:10.1080/09588221.2010.523285 